International Journal of Engineering \& Technology, $9(2)(2020) 326-332$
SPC
International Journal of Engineering \& Technology
Website: $w$ ww.sciencepubco.com/index.php/IJET
Research paper

\title{
Servqual: strategies to improve university library services
}

\author{
Ahmad hidayat sutawidjaya ${ }^{1 *}$, Lenny Christina Nawangsari ${ }^{2}$ \\ ${ }^{1}$ Doctoral Program Universitas Mercu Buana \\ ${ }^{2}$ Magister Manajemen Universitas Mercu Buana \\ *Corresponding author E-mail: a.h.sutawijaya@mercubuana.ac.id
}

\begin{abstract}
Over the past two decades, library development in both the functional and physical fields is inseparable from the change in the paradigm of libraries and librarians towards libraries. Increasing competitiveness in university library services is carried out through several aspects; one of which is through the improvement of facilities or infrastructure, products or services produced or personnel responsible for the product to provide customer satisfaction. The purpose of this research is to analysis the attributes of library services and performance of service quality attribute at Wuhan University of China and University of Mercu Buana. The research method used in this study is qualitative and quantitative research with a case study approach and Service Quality method. The population of this study were visitors at the Wuhan University and Mercu Buana University with sample of 100 peoples. As a result of this research libraries of the University of Mercu Buana priority should be given to the improvement are available room, convenience facilities, the availability of the closet, book collection added, Internet services by providing information search/catalogue and appearance of the staff are the dimensions of the material (X1). Reliability variable (X2) is formed with four level indicators expectation was perceived as very high by respondents. The response variable (X3) level expectations is perceived as very high by respondents. Variable reliability (X4), the answers respondents was perceived as very high by respondents. The empathy (X5) variable is very high by respondents, as seen from the responses of the average 4.65 found between a score of 4 (A) and a score of 5 (SA).
\end{abstract}

Keywords: Attributes of Certification Services; Customer Satisfaction; Service Quality; Library.

\section{Introduction}

In the industrial era 4.0, the quality of customer service is a very important thing that companies need to consider and improve. Because consumer demands are increasing on quality, techniques and quality assurance practices that exist need to be continuously improved.

Various attempts were made by the university in order to increase the ability to compete to meet the demand for quality desired by students. Current institutional attention towards improving quality. The current paradigm, quality is more determined by service providers, on the other hand now more quality is driven to be able to meet the needs of consumers.

The phenomena in this research based on observations and interviews, until now there are grievances felt by students, among others, have complained about the lack of patience and friendliness of the staff of the library to the students, the service did not respond quickly, there are often delays in the clock in the staff / library staff in performing the services, so that students have to wait. lack of clarity of employees / staff in providing information. Room service is less convenient, as seating is limited inside the library as a result of students standing, sitting cross-legged in the hallway, and in places that are not part of the lounge.

Other phenomena Indonesia's education level has declined. This is reflected in Indonesia's reading ability scores in the 2018 Program for International Student Assessment (PISA) issued by The Organization for Economic Co-operation and Development (OECD). Indonesia's position is also still below the OECD average score of 487. The Indonesian people's reading ability score in 2018 dropped to 371 from 39. The Indonesian score was 184 points adrift of China, which was ranked first. So that Indonesia's ranking dropped to position 72 out of 79 countries surveyed. At the Asian level, the reading ability of Indonesian students is below Malaysia, Brunei Darussalam and Thailand. Indonesia is only superior to the Philippines as shown in the graph (figure 1). 


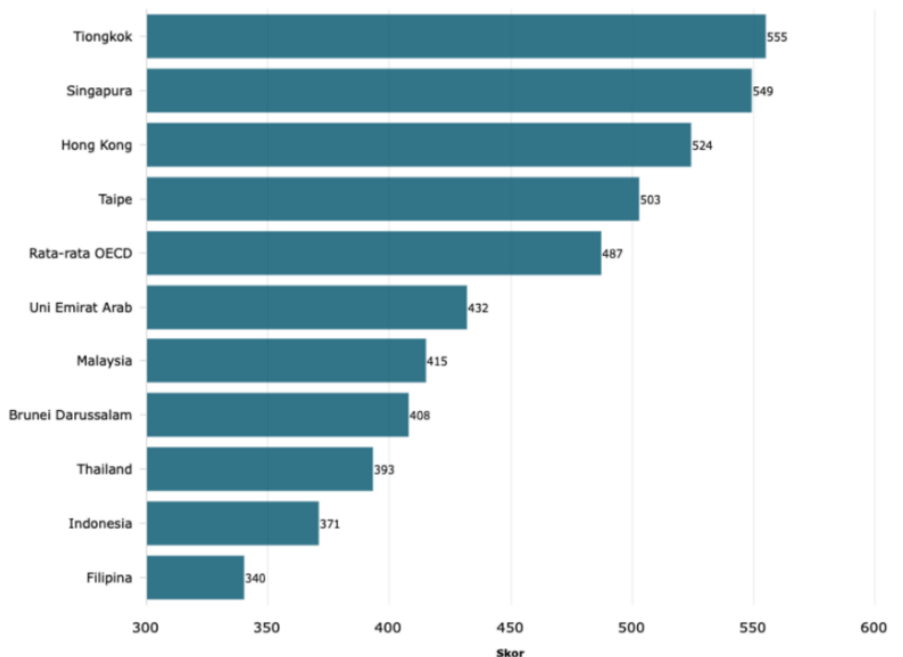

Fig. 1: Reading Ability Scores in 10 Asian Countries.

From the background of phenomena above some problems are what are the attributes of library services at Wuhan University and Mercu Buana University, which are the customer requirements of the service users? Then What service attributes need to be improved in quality and what service attributes need to be maintained in Wuhan University and Mercu Buana University?

In this study there are several theories used as references such as quality, service quality, the concept of service quality, Customer Perception, Customer Expectations, and Customer Satisfaction.

The quality. The paradigm of quality was previously defined by the service provider/producer; however, now higher quality is encouraged to be able to meet customer needs (customer requirements) (Sutawijaya, Mochtar, Nawangsari, 2018).

The quality of a product or service can be defined in the quality of its design, and the quality of its suitability for the design. Juran (Tunggal, 2002) defines quality as "fitness for use" meaning that users of a product or service must be able to fulfil what they need/want. According to Gaspersz (2001) Quality is a technical and management activist, through which we measure the quality characteristics of the product (goods and/or services), then compare the results with the specifications of the product that the customer wants, and take appropriate actions if differences are found between the performance actual and standard.

The Service Quality. A service is an activity or series of activities that are ordinarily intangible, but not always, in the interaction between the customer and the service provider. Sometimes physical resources or goods from the service provider, are used to provide solutions to Customers' problems (Gronross, in Sutawijaya, Mochtar, Nawangsari, 2018).

The SERVQUAL method is a method used to determine the quality of services based on the gap results, namely how customers' perceptions and expectations of the real services provided. The Servqual method is built on the comparison of two main factors, namely customer perceptions of perceived service and the expected service. If the reality is more than what the customer expects, then the service can be said to be of high quality, whereas if reality is less than the customer expects, then it is said to be of poor quality. Thus, the servqual method defines service quality as the difference between reality and expectations of the services that customers receive.

Zeithaml et. al (1990) revealed that there are five of the most dominant factors or determinants of service quality from the servqual concept:

1) Reliability, namely the ability to provide promised services reliably and accurately. In a broad sense, reliability means that the company gives its promises about providing, solving problems and pricing.

2) Responsiveness, namely awareness and desire to help customers and provide services quickly. This dimension emphasizes attention and accuracy when dealing with customer requests, questions and complaints.

3) Assurance (certainty), knowledge, courtesy, and the ability of employees to generate confidence and trust. This dimension may be very important in services that require a high level of trust where customers will feel safe and secure. Examples include banks, insurance, drugs and brokers.

4) Empathy (empathy) that personal care and attention given to customers. The essence of the empathy dimension is showing customers through the services provided that customers are special, and their needs can be understood.

5) Tangible (tangible), which is in the form of appearance of physical facilities, equipment, employees, and materials installed. This dimension describes the physical form and service that will be accepted by consumers. This includes the physical environment such as the exterior and interior of the building, the appearance of neat and attractive personnel when providing services.

The concept of service quality. Service Quality Analysis (servqual acronym) is a descriptive method to describe the level of customer satisfaction. The servqual is a scale selection that is concise but has a high level and truth that can be used by company management to better understand consumer perceptions and consumer expectations of services provided. The concept of servqual is used to calculate the gap between perceptions of consensus on services and expectations or expectations. The following is the formula: Q (Quality of service) $=\mathrm{P}($ Perceived service $)-\mathrm{E}($ Expected service $)$. 


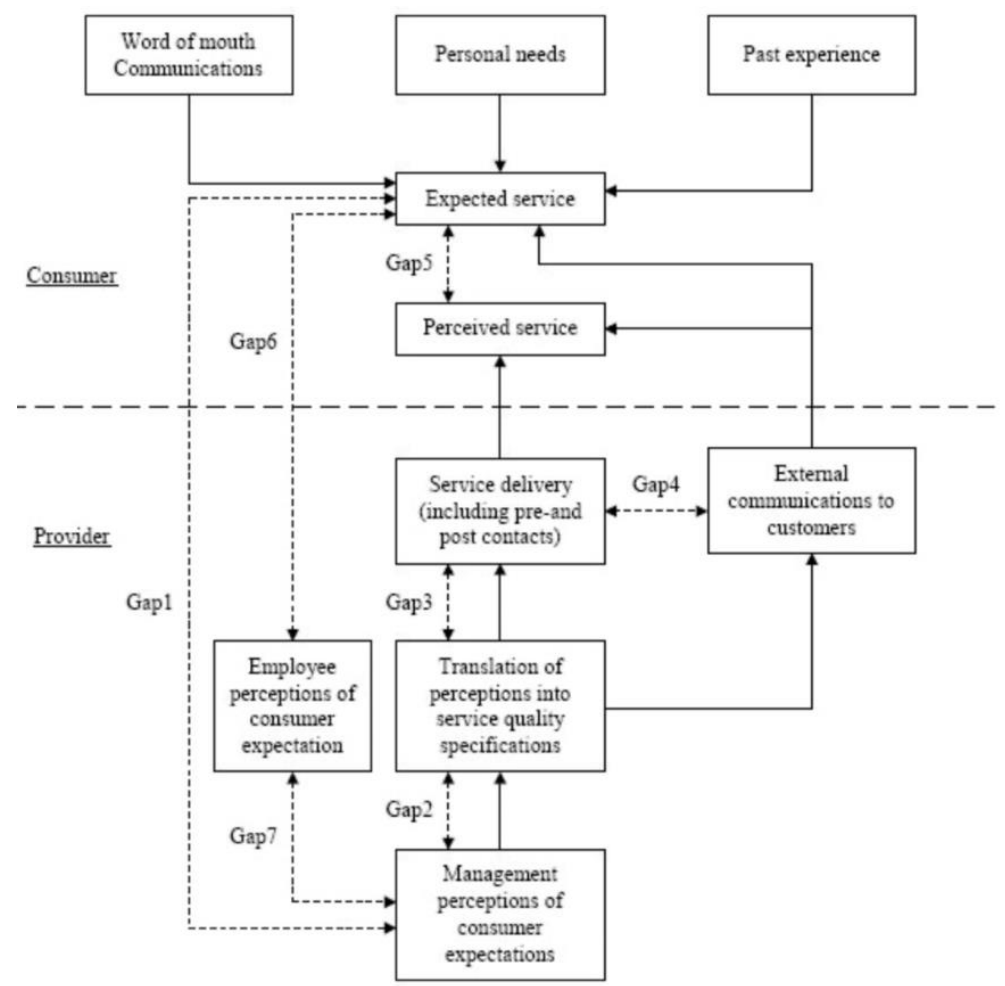

Fig. 2: The Concept of Service Quality.

Source: Zetthaml,et.al., 1990

Customer Perception. Perceptions are defined as processes through which others choose, organize, and interpret information in order to form a meaningful picture of the world. quality must start from the customer and end at the customer's perception. This means that the image of good quality is not based on the point of view or perception of the service provider, but based on the customer's point of view or perception (Kotler and Keller, 2006).

Customer Expectations. Customer expectations have a close relationship between determining the quality and customer satisfaction (Tjiptono, 2008). According to Olson and Dover (in Zeithaml et al., 1990), customer expectations or customer expectations are customer beliefs before trying or buying a product that is used as a standard or reference in assessing the performance of these products.

Customer Satisfaction. According to Zeithaml et al. (1990), customer satisfaction is influenced by perceptions of service quality, perceptions of product quality, price, and situational factors and personal factors. Then Kotler and Keller (2006) said that customer satisfaction is the extent to which the assumption of product performance meets buyer expectations. If the product's performance is lower than the customer's expectations, the buyer is satisfied or very happy.

\section{Research method}

The research method used in this research is qualitative and quantitative research with a case study approach and Service Quality method. The object of research is the Library at Wuhan University, China and Mercu Buana University, Indonesia. The population in this study were visitors at Wuhan University and Mercu Buana University with a sample of 100 people. The sampling technique is random sampling. The operational variable for this research are tangible; reliability; responsiveness; assurance and empathy. Which Tangible consists of Cleanliness of the library room; Arrangement of the room; Convenient library facilities; Availability of lockers; Complete collection of books; Internet facilities; Availability of information/catalog search facilities; and Nicety appearance of officers. Then for reliability variable the indicator consist of; timeliness of officers in providing services; Discipline of service time (opening / closing hours); Accuracy of officer information; and Ease of procedure to utilize available services. Next for the Responsiveness variable the indicator consists of Speed of staff in serving; Speed of officers in helping visitors who have difficulty; The responsiveness of the officers in responding to visitor requests; and The responsiveness of officers in responding to complaints / input from visitors.

Besides that the variable Assurance indicators consist of The officer has knowledge of the library; Courtesy officers when providing services; Hospitality of officers when providing services; Security of visitors when doing activities in the library. Finally for the variable Emphathy indicators consist of; The clerk really understands the needs of the visitor; and Officers give full attention to visitors.

\section{Result and discussion}

Analysis of the level of satisfaction of respondents is used to determine the level of satisfaction of respondents to the dimensions of service quality that has been provided by Mercubuana University and Wuhan China University. The analysis used is the Servqual score (service quality) in addition to showing the quality of services of an agency also shows consumer satisfaction in the institution. Negative Servqual $(-)$ indicates that there are indications of quality gaps in these quality attributes, while positive Servqual (+) indicates that there are indications of quality that is satisfying enough for consumers.

The values of Expectation, Realization, Expectation averages and Realization and Servqual scores for each attribute can be seen in Table. 1 for Mercubuana University and Table 2 for Wuhan China University, while for the Expectation and Realization average and each Servqual Score the dimensions can be seen in Table 3 for Mercu Buana University and Table 4 for Wuhan China University. 
Table 1: Expectation Rate, Realization Rate and Servequal Score for each Attribute at Mercubuana University

\begin{tabular}{|c|c|c|c|c|c|c|}
\hline Dimentions & Attribute & Expextation & Realization & $\begin{array}{c}\text { Expectation } \\
\text { everage }\end{array}$ & $\begin{array}{c}\text { Realization } \\
\text { everage }\end{array}$ & $\begin{array}{c}\text { Score } \\
\text { Servqual }\end{array}$ \\
\hline \multirow{8}{*}{ Tangible } & $\mathrm{X} 1.1$ & 238 & 185 & 4,76 & 3,7 & $-1,06$ \\
\hline & $\mathrm{X} 1.2$ & 237 & 174 & 4,74 & 3,48 & $-1,26$ \\
\hline & $\mathrm{X} 1.3$ & 237 & 177 & 4,74 & 3,54 & $-1,2$ \\
\hline & $\mathrm{X} 1.4$ & 241 & 175 & 4,82 & 3,5 & $-1,32$ \\
\hline & $\mathrm{X} 1.5$ & 240 & 171 & 4,8 & 3,42 & $-1,38$ \\
\hline & $\mathrm{X} 1.6$ & 239 & 172 & 4,78 & 3,44 & $-1,34$ \\
\hline & $\mathrm{X} 1.7$ & 239 & 174 & 4,78 & 3,48 & $-1,3$ \\
\hline & $\mathrm{X} 1.8$ & 235 & 176 & 4,7 & 3,52 & $-1,18$ \\
\hline \multirow{4}{*}{ Reliability } & $\mathrm{X} 2.1$ & 237 & 184 & 4,74 & 3,68 & $-1,06$ \\
\hline & $\mathrm{X} 2.2$ & 238 & 195 & 4,76 & 3,9 & $-0,86$ \\
\hline & $\mathrm{X} 2.3$ & 237 & 179 & 4,74 & 3,58 & $-1,16$ \\
\hline & $\mathrm{X} 2.4$ & 236 & 178 & 4,72 & 3,56 & $-1,16$ \\
\hline \multirow{4}{*}{ Responsiveness } & $\mathrm{X} 3.1$ & 236 & 176 & 4,72 & 3,52 & $-1,2$ \\
\hline & $\mathrm{X} 3.2$ & 235 & 173 & 4,7 & 3,46 & $-1,24$ \\
\hline & $\mathrm{X} 3.3$ & 234 & 176 & 4,68 & 3,52 & $-1,16$ \\
\hline & $\mathrm{X} 3.4$ & 229 & 172 & 4,58 & 3,44 & $-1,14$ \\
\hline \multirow{4}{*}{ Assurance } & $\mathrm{X} 4.1$ & 234 & 171 & 4,68 & 3,42 & $-1,26$ \\
\hline & $\mathrm{X} 4.2$ & 231 & 186 & 4,62 & 3,72 & $-0,9$ \\
\hline & $\mathrm{X} 4.3$ & 232 & 181 & 4,64 & 3,62 & $-1,02$ \\
\hline & $\mathrm{X} 4.4$ & 232 & 184 & 4,64 & 3,68 & $-0,96$ \\
\hline \multirow{2}{*}{ Emphaty } & $\mathrm{X} 5.1$ & 229 & 175 & 4,58 & 3,5 & $-1,08$ \\
\hline & $\mathrm{X} 5.2$ & 227 & 169 & 4,54 & 3,38 & $-1,16$ \\
\hline \multicolumn{2}{|c|}{ average } & 235,14 & 177,41 & 4,70 & 3,55 & $-1,15$ \\
\hline
\end{tabular}

Table 2: Expectation Rate, Realization Rate and Servqual Score of Each Attribute at Wuhan University

\begin{tabular}{|c|c|c|c|c|c|c|}
\hline Dimentions & Attribute & Expextation & Realization & $\begin{array}{c}\text { Expectation } \\
\text { everage }\end{array}$ & $\begin{array}{l}\text { Realization } \\
\text { everage }\end{array}$ & $\begin{array}{c}\text { Score } \\
\text { Servqual }\end{array}$ \\
\hline \multirow{8}{*}{ Tangible } & $\mathrm{X} 1.1$ & 228 & 207 & 4,56 & 4,14 & $-0,42$ \\
\hline & $\mathrm{X} 1.2$ & 220 & 192 & 4,4 & 3,84 & $-0,56$ \\
\hline & $\mathrm{X} 1.3$ & 232 & 203 & 4,64 & 4,06 & $-0,58$ \\
\hline & $\mathrm{X} 1.4$ & 222 & 190 & 4,44 & 3,8 & $-0,64$ \\
\hline & $\mathrm{X} 1.5$ & 225 & 196 & 4,5 & 3,92 & $-0,58$ \\
\hline & $\mathrm{X} 1.6$ & 235 & 199 & 4,7 & 3,98 & $-0,72$ \\
\hline & $\mathrm{X} 1.7$ & 223 & 202 & 4,46 & 4,04 & $-0,42$ \\
\hline & $\mathrm{X} 1.8$ & 216 & 194 & 4,32 & 3,88 & $-0,44$ \\
\hline \multirow{4}{*}{ Reliability } & $\mathrm{X} 2.1$ & 213 & 194 & 4,26 & 3,88 & $-0,38$ \\
\hline & $\mathrm{X} 2.2$ & 218 & 199 & 4,36 & 3,98 & $-0,38$ \\
\hline & $\mathrm{X} 2.3$ & 218 & 192 & 4,36 & 3,84 & $-0,52$ \\
\hline & $\mathrm{X} 2.4$ & 214 & 201 & 4,28 & 4,02 & $-0,26$ \\
\hline \multirow{4}{*}{ Responsiveness } & $\mathrm{X} 3.1$ & 224 & 200 & 4,48 & 4 & $-0,48$ \\
\hline & $\mathrm{X} 3.2$ & 226 & 198 & 4,52 & 3,96 & $-0,56$ \\
\hline & $\mathrm{X} 3.3$ & 226 & 192 & 4,52 & 3,84 & $-0,68$ \\
\hline & $\mathrm{X} 3.4$ & 219 & 188 & 4,38 & 3,76 & $-0,62$ \\
\hline \multirow{4}{*}{ Assurance } & $\mathrm{X} 4.1$ & 221 & 194 & 4,42 & 3,88 & $-0,54$ \\
\hline & $\mathrm{X} 4.2$ & 215 & 196 & 4,3 & 3,92 & $-0,38$ \\
\hline & $\mathrm{X} 4.3$ & 216 & 182 & 4,32 & 3,64 & $-0,68$ \\
\hline & $\mathrm{X} 4.4$ & 227 & 197 & 4,54 & 3,94 & $-0,6$ \\
\hline \multirow{2}{*}{ Emphaty } & $\mathrm{X} 5.1$ & 223 & 188 & 4,46 & 3,76 & $-0,7$ \\
\hline & $\mathrm{X} 5.2$ & 225 & 184 & 4,5 & 3,68 & $-0,82$ \\
\hline & & 222,09 & 194,91 & 4,44 & 3,90 & $-0,54$ \\
\hline
\end{tabular}

Table 3: Expectation Rates, Realization Rates and Servqual Scores for each Dimension at Mercu Buana University

\begin{tabular}{|c|c|c|c|c|}
\hline Dimension & Expectation & Realization & $\begin{array}{c}\text { Score } \\
\text { Servqual }\end{array}$ & Explanation \\
\hline Tangible (X1) & 4,765 & 3,51 & $-1,255$ & Not satisfied \\
\hline Reliability (X2) & 4,74 & 3,68 & $-1,06$ & Not satisfied \\
\hline Responsiveness (X3) & 4,67 & 3,485 & $-1,185$ & Not satisfied \\
\hline Assurance (X4) & 4,645 & 3,61 & $-1,035$ & Not satisfied \\
\hline Emphaty (X5) & 4,56 & 3,44 & $-1,12$ & Not satisfied \\
\hline Average & 4,676 & 3,545 & $-1,131$ & Not satisfied \\
\hline
\end{tabular}

Table 4: Expectation Rates, Realization Rates and Servqual Scores for each Dimension at Wuhan University

\begin{tabular}{|c|c|c|c|c|}
\hline Dimension & Expectation & Realization & $\begin{array}{c}\text { Score } \\
\text { Servqual }\end{array}$ & Explanation \\
\hline Tangible (X1) & 4,50 & 3,96 & $-0,55$ & Not satisfied \\
\hline Reliability (X2) & 4,32 & 3,93 & $-0,39$ & Not satisfied \\
\hline Responsiveness (X3) & 4,48 & 3,89 & $-0,59$ & Not satisfied \\
\hline Assurance (X4) & 4,40 & 3,85 & $-0,55$ & Not satisfied \\
\hline Emphaty (X5) & 4,48 & 3,72 & $-0,76$ & Not satisfied \\
\hline Rata-rata & 4,43 & 3,87 & $-0,57$ & \\
\hline
\end{tabular}

Satisfaction Score Analysis (Score Servqual) is used to identify the dimensions and aspects in each of these dimensions that require quality improvement. If the customer satisfaction score (Servqual Score) is less than zero then it is categorized that the consumer is not satisfied with the services provided. If it is known that the satisfaction value (Score Servqual) of consumers has a value equal to or more than zero then it is categorized that the customer is satisfied with the services provided. In Table 1 and Table 3. that is at Mercu Buana University, it can be seen that respondents are not satisfied with the services provided by Mercu Buana University. This can be seen from the satisfaction value (Servqual Score) which is negative for all dimensions and dimension attributes. Likewise at Wuhan University, China, in Table 2 and Table 4, it can be seen that respondents are not satisfied with the services provided by Wuhan University, China. This is seen from the satisfaction score (Servqual Score) which is negative for all dimensions and dimension attributes. 


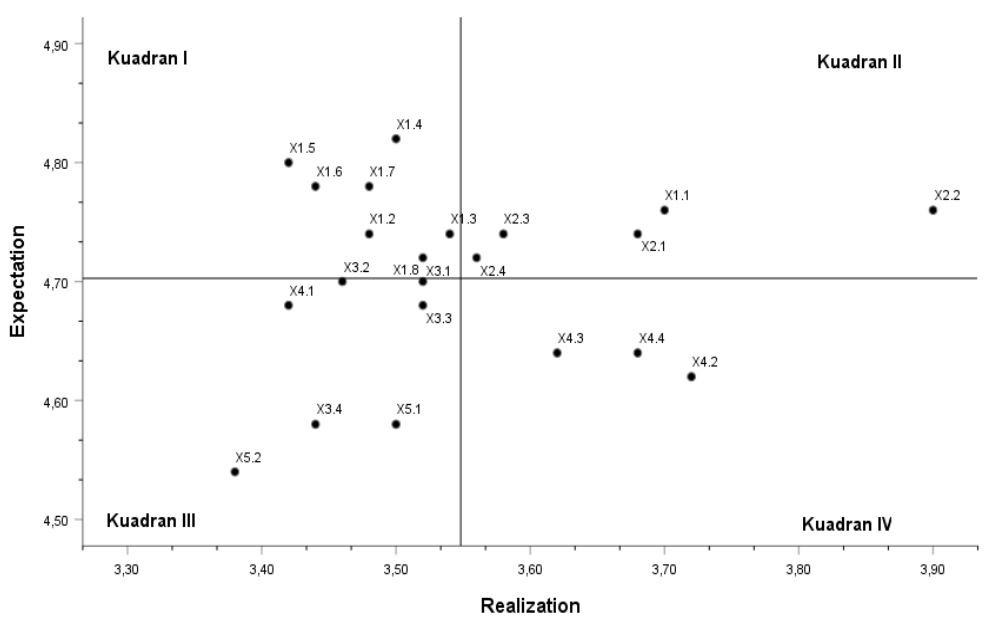

Fig. 3: Translation of Attribute Position in Cartesian Diagrams at Mercu Buana University.

The Cartesian diagram in figure 3 illustrates the mapping based on the level of Realization and Expectation, so that the Mercu Buana University makes it possible to make improvements, evaluations and possibly make improvements.

The interpretations of each quadrant for the Cartesisu Diagram at Mecu Buana University are:

1) Quadrant I (Top Priority)

Areas that contain attributes that are considered important but the University of Mecu Buana has not carried out in accordance with the wishes of the respondents so that it disappoints or does not provide satisfaction. The attributes included in quadrant I are Room Arrangement (X1.2), Convenience of library facilities (X1.3), Locker Availability (X1.4), Completed book collection (X1.5), Internet Facilities (X1.6), Availability means of searching information /catalog (X1.7) and neatness of the appearance of officers (X1.8) which are the dimensions of Tangible (X1). This dimension must be prioritized to be improved by Mercubuana University

2) Quadrant II (Maintain Performance)

The area that contains the attributes is considered important by the respondent and these attributes are in accordance with the perceived respondent. Attributes included in quadrant II are cleanliness attributes of the library room (X1.1) which is an attribute of the Tangible dimension (X1). In addition, the timeliness of officers in providing services (X2.1), Discipline of service time (opening / closing hours) (X2.2), Accuracy of officer information (X2.3), Ease of procedures for utilizing available services (X2. 4) which is an attribute of the Reliability dimension (X2). The attributes included in this quadrant must be retained by the Mercu Buana University, because all of these attributes make these attributes superior in the eyes of respondents.

3) Quadrant III (Low Priority)

Areas that contain attributes that are considered less important by respondents and in reality their performance is not too special. Attributes that enter quadrant III are the attributes of the speed of officers in serving (X3.1), the speed of officers in assisting visitors who have difficulty (X3.2), the responsiveness of officers in responding to requests of visitors (X3.3), the responsiveness of officers in responding to complaints / input from visitors (X3.4) which is an attribute of the Responsiveness dimension (X3). In addition, the Attribute Officer has knowledge of the library (X4.1) which is an attribute of the Assurance dimension (X4). In addition, the Attendant's attributes truly understand the needs of the visitor (X5.1) and the Attendant pays full attention to the visitor (X5.2) which is an attribute of the Emphaty dimension (X5). The increase in attributes included in this quadrant can be reconsidered because of their effect on the benefits felt by small respondents.

4) Quadrant IV (Excessive)

Areas that contain attributes deemed unimportant by respondents and are considered too excessive. The attributes included in quadrant IV are the courtesy attributes of the officers when providing services (X4.2), the friendliness of officers when providing services (X4.3), the safety of visitors while on the move in the library (X4.4) which is an attribute of the Assurance dimension (X4). In this case the Mercu Buana University may need to reduce the level of performance for the attributes included in this quadrant.

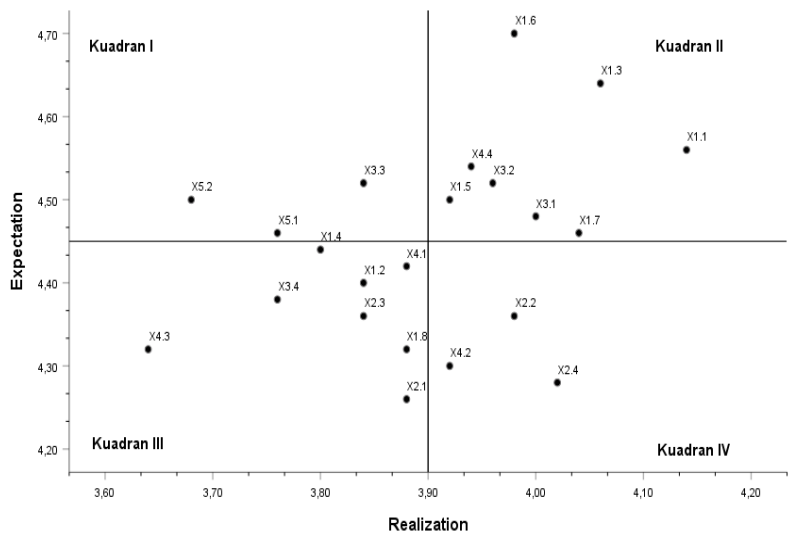

Fig. 4: Attribute Positions in Cartesian Diagrams at Wuhan University of China.

The Cartesian diagram in Figure 4 illustrates the mapping based on the level of Realization and Expectation, so that the University of Wuhan China makes it possible to make improvements, evaluations and possibly make improvements. The interpretations of each quadrant for the Cartesisu Diagram at Wuhan University are:

1) Quadrant I (Top Priority) 
The attribute included in quadrant I is the staff's responsiveness in responding to visitor requests (X3.3) which is a dimension of Responsiveness (X3). In addition, the attributes of the Officer really understand the needs of the visitor (X5.1) and the Officer gives full attention to the visitor (X5.2) which is the Empathy Dimension (X5). This dimension must be prioritized for improvement by Wuhan University of China.

2) Quadrant II (Maintain Performance)

The area that contains the attributes is considered important by the respondent and these attributes are in accordance with the perceived respondent. Attributes included in quadrant II are cleanliness of library (X1.1), comfort of library facilities (X1.3), complete collection of books (X1.5), internet facilities (X1.6), availability of information/catalogue search facilities (X1.7) which is an attribute of the Tangible dimension (X1). In addition, the speed of officers in serving (X3.1) and the speed of officers in assisting visitors who have difficulty (X3.2) which is an attribute of the Responsiveness dimension (X3). In addition, the Security attribute of visitors when doing activities in the library (X4.4) which is an attribute of the Assurance Dimension (X4). The attributes included in this quadrant must be retained by Wuhan University of China, because all of these attributes make these attributes superior in the eyes of respondents.

3) Quadrant III (Low Priority)

The attributes that enter quadrant III are the room arrangement (X1.2), locker availability (X1.4) and attendant appearance neatness (X1.8) which are attributes of the Tangibles dimension (X1). In addition, the attributes of timeliness of officers in providing services (X2.1) and accuracy of officer information (X2.3) are attributes of the dimensions of reliability (X2). In addition, the Attribute Officer's response in responding to complaints / input from visitors (X3.4) is an attribute of the Responsiveness dimension (X3). In addition, the Attributes of Officers have knowledge of the library (X4.1) and the Hospitality of the officers when providing services (X4.3) which are attributes of the Assurance dimension (X4). The increase in attributes included in this quadrant can be reconsidered because of their effect on the benefits felt by small respondents.

4) Quadrant IV (Excessive)

The attributes included in quadrant IV are the Discipline attribute of service time (opening/closing hours) (X2.2) and Ease of procedures for utilizing available services (X2.4) which are attributes of the Reliability dimension (X2). In addition, the Attributes of the officers when providing services (X4.2) are attributes of the Assurance Dimension (X4). In this case maybe the Wuhan University of China needs to reduce the level of performance for the attributes included in this quadrant.

\section{Conclusions}

Based on the above explanation and research, it can be concluded that the libraries at Mercu buana University must be prioritized improved are Room Arrangement (X1.2), Convenience of library facilities (X1.3), Locker Availability (X1.4), Completed book collection (X1.5), Internet Facilities (X1.6), Availability means of searching information / catalog (X1.7) and neatness of the appearance of officers (X1.8) which are the dimensions of Tangible (X1). Reliability variable (X2) is formed with 4 indicators at the level of expectation was perceived to be very high by respondents. The Responsiveness Variable (X3) is formed with 4 indicators. The Mercu buana University and Huwan University showed the Responsiveness Variable (X3) at the level of expectation was perceived to be very high by respondents. The Assurance variable (X4) is formed with 4 indicators. Based on the perception index of respondents Mercu Buana University and Huwan University answers was perceived to be very high by respondents. Variable Empathy (X5) is formed with 2 indicators namely. The level of expectation is perceived to be very high by respondents, as seen from the average respondent's answers of 4.65 which lie between a score of 4 (A) and a score of 5 (SA).

However, both of the University library must be improved are as the staff's responsiveness in responding to visitor requests (X3.3) which is a dimension of Responsiveness (X3). In addition, the attributes of the Officer really understand the needs of the visitor (X5.1) and the Officer gives full attention to the visitor (X5.2) which is the Empathy Dimension (X5).

\section{Recommendations}

To achieve high levels of satisfaction, universities need an understanding of what students want, by developing the commitment of everyone in the institution to meet the needs of students. Establish work standards in important parts of student services, such as the library and facilities. Library university need to improve the library staff's pedagogical ability on an ongoing basis. And Comparative studies at libraries in other universities, to find the strengths and weaknesses of libraries that are often used as students to compare services.

\section{Acknowledgements}

The Authors thanks to Rector Mercu Buana University, Jakarta on behalf Professor Ngadino Surip and Profesor Ma Ying, Wuhan University, China for supporting author to complete this article.

\section{References}

[1] Aydin, K., \& Yildirim, S. (2012). The measurement of service quality with servqual for different domestic airline firms in Turkey. Serbian Journal of Management, 7(2), 219-230. https://doi.org/10.5937/sjm7-1317.

[2] Brysland, A., \& Curry, A. (2001). Service improvements in public services using SERVQUAL. Managing Service Quality: An International Journal. https://doi.org/10.1108/09604520110410601.

[3] Gaspersz, V. (2001). Total Quality management. PT. Gramedia Pustaka Utama, Jakarta. International Standard Organization: ISO 9000:2015. Quality Management Systems: Fundamentals and Vocabulary.

[4] Hirmukhe, J. (2012). Measuring internal customers' perception on service quality using SERVQUAL in administrative services. International journal of scientific and research publications, 2(3), 1-6.

[5] Jiwantara, K., Sutrisno, A., \& Neyland, J. S. C. (2013). Penerapan Metode Servqual Untuk Evaluasi dan Perbaikan Kualitas Pelayanan pada Kegiatan Penyuluhan Bahasa Indonesia Praktis di Balai Bahasa Provinsi Sulawesi Utara. Jurnal Online Poros Teknik Mesin UNSRAT, 2(1).

[6] Kotler, P., \& Keller, L. (2006). K. (2006). Marketing management, 12.

[7] Mursaleen, M., Ijaz, M., \& Kashif, M. (2014). Service quality of news channels: a modified SERVQUAL analysis. Observatorio (OBS*), 8(1), 171188. 
[8] Parasuraman, A., Berry, L. L., \& Zeithaml, V. A. (1991). Refinement and reassessment of the SERVQUAL scale. Journal of retailing, 67(4), 420.

[9] Parasuraman, A., Berry, L., \& Zeithaml, V. (2002). Refinement and reassessment of the SERVQUAL scale. Journal of retailing, 67(4), 114.

[10] Parasuraman, A., Zeithaml, V. A., \& Berry, L. L. (1985). A conceptual model of service quality and its implications for future research. Journal of marketing, 49(4), 41-50. https://doi.org/10.1177/002224298504900403.

[11] Parasuraman, A., Zeithaml, V. A., \& Berry, L. L. (1988). Servqual: A multiple-item scale for measuring consumer perc. Journal of retailing, 64(1), 12.

[12] Parasuraman, A., Zeithaml, V., \& Berry, L. L. (1990). Delivering quality service: Balancing customer perceptions and expectations

[13] Saravanan, R., \& Rao, K. S. P. (2007). Service Quality from the Customer's Perspective: an empirical investigation. Quality Management Journal, 14(3), 15-22. https://doi.org/10.1080/10686967.2007.11918032.

[14] Sekaran, U., \& Bougie, R. (2003). Research Methods for Business, A Skill Building Approach, John Willey \& Sons. Inc. New York.

[15] Seth, N., Deshmukh, S. G., \& Vrat, P. (2005). Service quality models: a review. International journal of quality \& reliability management. https://doi.org/10.1108/02656710510625211.

[16] Sutawijaya, A. H., Mochtar, I. L., \& Nawangsari, L. C. (2018). Quality certification and customer satisfaction. European Research Studies Journal, Volume XXI, Issue 3, pp. 266 - 279 https://doi.org/10.35808/ersj/1059.

[17] Tjiptono, F., \& Chandra, G. (2005). Service, quality \& satisfaction. Yogyakarta: Andi Offset.

[18] Zeithaml, V. A., Parasuraman, A., Berry, L. L., \& Berry, L. L. (1990). Delivering quality service: Balancing customer perceptions and expectations. Simon and Schuster. 